\title{
Yabancı dil olarak Türkçe öğretiminde Gazi Üniversitesi Bı Seviyesi Ders Kitabı dinleme bölümünün incelenmesi
}

Mesut GÜN1

\section{Medine BAKIRDÖĞEN²}

\begin{abstract}
APA: Gün, M.; Bakırdöğen, M. (2020). Yabancı dil olarak Türkçe öğretiminde Gazi Üniversitesi B1 Seviyesi Ders Kitabı dinleme bölümünün incelenmesi. RumeliDE Dil ve Edebiyat Araştırmaları Dergisi, (Ö7), 59-79. DOI: 10.29000/rumelide.808235.
\end{abstract}

\section{$\ddot{\mathbf{O} z}$}

Günümüzde Türkçenin yabancı dil olarak öğretimi önem kazanan bir alandır. Türkçenin yabancı dil olarak öğretiminde dört temel dil becerisi vardır. Dinleme diğer becerilere göre ayrı bir önem arz etmektedir. Çünkü dinleme, anne karnında işitilen seslerin anlam kazanmasıyla başlayan ilk dil becerisidir. Dinleme, doğal olarak gelişir ve diğer becerilerinin gelişmesinde önemli rol oynar. Dinleme becerisi düşünme becerisini destekleyen, bir süreç sonunda kendini geliştirebilen bir beceri alanı olarak kabul edilmelidir. Bu çalışmanın temel amacı yabancılara Türkçe öğretiminde kullanılan Gazi Üniversitesi B1 seviyesi ders kitabındaki dinleme metinlerinin öğrenci seviyesine uygunluğunun incelenmesidir. Çalışmada doküman incelemesi yöntemine başvurulmuştur. Bu bağlamda Gazi Üniversitesi B1 seviyesi ders kitabındaki dinleme metinleri Diller İçin Avrupa Ortak Başvuru Metninde yer alan kriterlere göre incelenmiştir. İncelenen noktalar şunlardır; içerik, soru tipi, dil bilgisi, kelimelerin seviyeye uygunluğu, hız ve anlaşılırlık, görsel kullanımı, dinlemenin varsa kültür aktarım boyutu. Araştırma sonucunda, dinleme ses kayıtlarının Gazi Üniversitesi Yabancılara Türkçe Öğretimi B1 Seviyesi Ders Kitabındaki dinleme etkinliklerinde dinleme öncesi ve dinleme sonrası etkinliklere yer verilmemiştir. Dinleme öncesi etkinliklere yer verilmesinin öğrencide farklı dinleme özelliklerinin gelişmesine katkı sağlayacağı düşünülmektedir. Gazi Üniversitesi ders kitabındaki okuma metinleri ve dinleme metinleri arasında içerik bağlamında bir ilişki yoktur. Bu durumun dinleme becerisinde anlama ve anlamlandırmayı desteklemediği düşünülmektedir. Dil becerileri birbirinden farklıdır. Ancak birbirini destekler. Dil öğretimi kitaplarında da birbirini destekler etkinliklere yer verilmesi önerilmektedir.

Anahtar Sözcükler: Yabancılara Türkçe öğretimi, ders kitabı, dinleme etkinlikleri, inceleme

\section{Examination of Gazi University B1 level textbook listening department in teaching Turkish as a foreign language}

\begin{abstract}
Today, teaching Turkish as a foreign language is an important field. There are four basic language skills in teaching Turkish as a foreign language. Listening has got special importance compared to other skills, because listening is the first language skill that begins with the meaning of sounds heard in mother's womb. Listening develops naturally and plays an important role in the development of other skills. Listening skill should be accepted as a skill field that supports thinking

1 Doç. Dr., Mersin Üniversitesi, Eğitim Fakültesi, Türkçe ve Sosyal Bilimler Eğitimi Bölümü, Türkçe Eğitimi ABD (Mersin, Türkiye), mesutgun@mersin.edu.tr, ORCID ID: 0000-0001-9663-1066 [Makale kayıt tarihi: 09.07.2020-kabul tarihi: 20.10.2020; DOI: 10.29000/rumelide.808235]

2 Öğr. Gör., Erciyes Üniversitesi, Rektörlük, ERSEM (Kayseri, Türkiye), mbakirdogen@gmail.com, ORCID ID: ooooo003-0820-7199
\end{abstract}


Examination of Gazi University B1 level textbook listening department in teaching Turkish as a foreign language / M. Gün; M. Bakırdöğen (pp. 59-79)

\begin{abstract}
skill and can improve itself at the end of a process. The main purpose of this study is to examine the appropriateness of the listening texts of Gazi University B1 level textbook used in teaching Turkish to foreigners to the student level. In the study, document review method was used. In this context, the listening texts in Gazi University B1 level textbook were examined according to the criteria in the European Common Application Text. The points examined are as follows; content, question type, grammar, conformity of words to level, speed and comprehensibility, visual use, culture transfer dimension of listening. As a result of the research, pre-listening and post-listening activities were not included in the listening activities of Gazi University, Teaching Turkish to Foreigners B1 Level Course Book. It is considered that giving place to pre-listening activities will contribute to the development of different listening features in the student. There is no relation in terms of content between reading texts and listening texts in Gazi University textbook. It is contemplated that this situation does not support understanding and comprehension in listening skill. Language skills are different. But they support each other. It is recommended to include activities supporting each other in language teaching books.
\end{abstract}

Keywords: Teaching Turkish to foreigners, textbook, , listening activies, examination

\title{
Giriş
}

Türkçeye duyulan ilgi çeşitli nedenlerle her geçen gün artmıştır. Bu sebeple yabancllara Türkçe öğretimi son zamanlarda gittikçe önem kazanan bir alan olmuștur. Bu süreçte yabancllara Türkçe öğretiminde dört temel beceri vardır. Bunlar okuma, anlama, yazma ve dinlemedir. Her bir becerinin öğretimi oldukça önemlidir. Ancak dil eğitiminin iletişim boyutu içerisinde dinleme becerisinin ayrı bir yeri vardır.

Dinleme becerisi, dil öğrenmenin ilk adımıdır. Dinleme becerisi öğretmen ders öğretim ortamına girdiği andan itibaren bir "merhaba" ile başlar. Bu bağlamda öğrenci öğretmeni önce işitir, sonra anlar ve işittiğini anlamlandırır.

Dil bir bütündür. Dilin farklı yönlerini oluşturan dinleme, konuşma, yazma ve okuma birbirlerine sıkı bir şekilde bağlıdır, birbiriyle ilişkili ve birbirinin tamamlayıcısıdır(Dara 2000,Aktaş ve Gündüz 2007).

Dil öğretiminde dinleme, karmaşık bir süreçten oluşmaktadır (Rost, 2001). Dil eğitiminde dinleme, genellikle 3 aşamada gerçekleştirilir: Dinleme öncesi, dinleme sırası ve dinleme sonrası. Dinleme öncesi, ön hazırlık aşamasıdır. Bu aşamada öğrenci dinleme metninin içeriği konusunda bilgilendirilir. Öğrencinin hazır bulunuşluk seviyesi kontrol edilir. Öğrenci dinleme metninin sorularını okur. Bu sebeple öğrenciye soruları okuması için belirli bir süre verilir. Bu süre soruların uzunluğuna göre değişebilir. Öğrenci soruları okuduktan sonra metin içerisinde bilinmeyen yeni kelimeler varsa, öğretmen tarafından bu kelimeler örneklendirilerek aktarılır. Hazırlık aşaması hem fiziksel hem de zihinsel olmak üzere iki boyutta ele alınmaktadır.

Dinleme sırasında ise öğrencilere cd veya internet üzerinden metin vb. etkinlikler dinletilir. Burada amaç öğrencinin her şeyi harf harf dinleyip kaydetmesi değil, stratejik dinleyerek çıarımda bulunmasını sağlamaktır. Öğrenci metnin genelini anlayıp anlamlandırmalıdır. Metnin verdiği mesajı yakalamalı bu doğrultuda dinlediği metnin sorularına cevap vermelidir.

Dinleme sonrası ise genel değerlendirme aşamasıdır. Bu değerlendirme öğrenciler ve öğretmen tarafından birlikte yapılan çoklu değerlendirmedir. Öncelikle öğrencilerden dinledikleri metnin

Adres

Kurklareli Üniversitesi, Fen Edebiyat Fakültesi, Türk Dili ve Edebiyat Bölümü, Kayalı Kampüsü-Kırklareli/TÜRKIYYE e-posta: editor@rumelide.com 
sorularını cevaplamaları beklenir. Bu cevapların öğretmen tarafından doğruluğu takip edilir. Öğretmen öğrencilere dönüt vererek metni cevaplarlar. Ayrıca metnin ana fikri öğrenci ve öğretmen tarafından ele alınır.

Dinleme becerisini geliştirmek için genellikle ders kitaplarının her ünitesinde dört dinleme etkinliği bulunmaktadır. Bu dinleme etkinlikleri genel olarak boşluk doldurma, sıralama, düzeltme, eşleştirme, yazma, sorulara cevap verme, dinleme sorularını bütünlük içinde yanıtlayarak bir metin oluşturma vb. dir. Her bir etkinliğin işlevsel boyutu farklıdır.

\section{Çalışmanın amacı}

Çalışmanın amacı TÖMER’lerde kullanılan yabancılara Türkçe öğretimi ders kitabı olan Gazi Üniversitesi B1 dinleme metinlerini Avrupa Ortak Başvuru Metninde yer alan ölçütlere göre inceleyerek yabancı dil olarak Türkçe öğretiminde dinleme becerisinin gelişimine katkı sunmaktır. Bu temel amaç çerçevesinde Avrupa Ortak Başvuru Metni (2001) dikkate alınarak üç alan uzmanından da görüş alınarak aşağıdaki alt amaçlar çerçevesinde araştırma yapılmıştır.

\section{Alt amaçlar}

1. Dinleme etkinliğinin konu olarak analizi

2. Etkinlikte yer alan soru tipleri ( çoktan seçmeli, doğru yanlış, açık uçlu vb.)

3. Dinleme metninin dil bilgisi açısından seviyeye uygunluğu

4. Dinlemede kullanılan kelimelerin seviyeye uygunluğu ve açıklığı

5. Dinlemede varsa kullanılan görseller ve görsel ile metnin uygunluğu

6. Dinleme metninin kültür aktarımı yönü

7. Tavsiyeler

\section{Yöntem}

Çalışmada, nitel araştırma yaklaşımı kapsamında bulunan doküman incelemesi yönteminden faydalanılmıştır. "Doküman incelemesi, araştırılması hedeflenen olgu ve olaylar hakkında bilgi içeren yazılı materyallerin analizini kapsar” (Yıldırım ve Şimşek, 2013, s. 217). Yıldırım ve Şimşek’e (2013) göre doküman incelemesi nitel araştırmalarda tek başına kullanılabilmektedir.

\section{Verilerin toplanması ve analizi}

Araştırma kapsamında Gazi Üniversitesi B1 seviye ders kitabının seçilme sebebi yabancılara Türkçe öğretiminde ilgili kitabın yaygın olarak kullanılması ve B1 seviye dinleme bölümüyle ilgili herhangi bir çalışma yapılmadı̆̆ının belirlenmesidir. Bu kapsamda yukarıda da belirtildiği üzere nitel araştırma yöntemlerinden doküman analizi kullanılarak ilgili kitap üzerinde çalışılmıştır. 
Examination of Gazi University B1 level textbook listening department in teaching Turkish as a foreign language / M. Gün; M. Bakırdöğen (pp. 59-79)

\section{Bulgular ve yorum}

Bu bölümde doküman incelenmesi sonucunda elde edilen bulgulara ve yorumlara yer verilmektedir.

\section{Dinleme 1}

A) DiNLEME
A) Dinlediğiniz diyaloğa göre cümleleri ișaretleyiniz.
(Doğru: $\checkmark$, Yanlıș: $x$ )
Sertab Erener 1974 ylında doğdu.
Müziğe keman dersleriyle bașladı.
Türkiye'yi 47. Eurovision Șarkı Yarıșması'nda
başarryla temsil etti.
Müziğe annesinin desteğiyle bașlamıștır.
"Sakin Ol" adlı parçayla tanınmıștır.

Şekil 1. Gazi Üniversitesi yabancılar için Türkçe ders kitabı dinleme 1 görseli, 1. Ünite, Sayfa 7: “Sertap’la Söyleşi”

Dinleme 1 etkinliği incelendiğinde, metinde tema olarak şarkıcı Sertap Erener'le olan temsili bir röportaja yer verilmiştir. Etkinlikte doğru ve yanlış soru tipi kullanılmıştır. Soru sayısı beştir. Etkinlik metni Avrupa dil portfolyosuna göre B1 dil bilgisi kurallarına uygundur. Kullanılan kelimeler B1 seviyesi için uygun görülebilir. Etkinlikte görsel kullanılmamıştır. Görsel kullanımı metnin daha anlaşılır olmasını sağlayabilir. Bu açıdan Sertap Erener'le yapılan bir röportaj resmine yer verilerek metinle görsel içeriği uyumlu hale getirilerek öğrencinin duyduğunu somutlaştırarak daha rahat anlamlandırması sağlanabilir.

\section{Dinleme 2}

\section{DINLEME}

A) Așağıdaki soruları dinlediğiniz diyaloğa göre cevaplandırınız.

1. Sunucu, Ziya Bey'den hangi konu hakkında bilgi almaktadır?
a) sosyal medya
b) bilgisayar yazli mlar
c) eğlence programlan
d) kültür ve sanat

2. Ziya Bey, așağıdaki görüșlerden hangisini savunmaktadır?

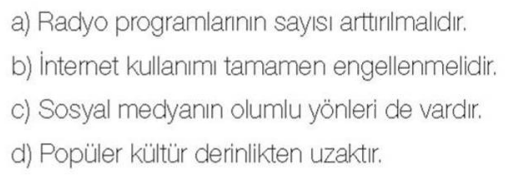

ekil 2. Gazi Üniversitesi yabancılar için Türkçe ders kitabı dinleme 2 görseli, 1. Ünite, Sayfa 11: "Sosyal Medya"

Dinleme metninde tema olarak, bir sunucunun sosyolog olan Ziya Bey'le yapmış olduğu röportaj ele alınmıştır. Sunucu sosyal medya hakkında sosyoloğa sorular sormaktadır. Etkinlik iki bölümden oluşmaktadır. Etkinliğin ilk bölümünde iki çoktan seçmeli soruya yer verilmiştir. İkinci bölümünde 
doğru ve yanlış soru tipi kullanılmıştır. Soru sayısı beştir. Metinde dil bilgisi yapısı olarak genellikle fiilimsilere (Tartışılan, geçen, olarak, haberleşerek vb) yer verilmiştir. Metinde kullanılan kelimeler genellikle B1 öğrenci seviyesine uygun görülebilir. Dinleme metninin içeriği bir röportaj olduğu için metnin iki seslendireni bulunmaktadır. Metni seslendiren temsili sunucu net ve anlaşlırken, metni seslendiren temsili psikolog için aynı durum geçerli değildir. Boğuk bir ses tonu ve duraklamalarda nefes alıp vermesi dinleme metninin anlaşılırlığını zorlaştırmaktadır. Etkinlikte görsel kullanılmamıştır. Sosyal medya genellikle herkes tarafından bilinen bir kavram olduğu için metnin görselle desteklenmemesi kabul edilebilir.

\section{Dinleme 3}

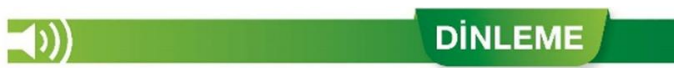

A) Așağıdaki soruları dinlediğiniz diyaloğa göre cevaplandırınız.

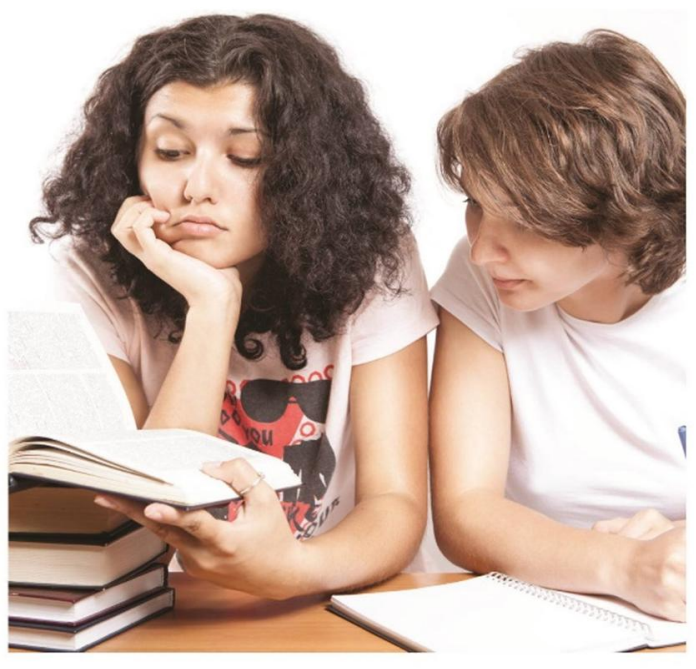

1. Fatma, Gülce'yle neden konușmak istiyor?
a) ödevine yardım etmesi için
b) söylediği kitabı okuması için
c) engellilere bilgisayarını vermesi için
d) bir projeye onu da katmak için

2. Proje ne ile ilgilidir?

$$
\begin{aligned}
& \text { a) ders kitaplannı seslendime } \\
& \text { b) engelliler için kitap seslendirme } \\
& \text { c) ses stüdyosu sistemi } \\
& \text { d) kütüphanenin intemet sitesi }
\end{aligned}
$$

3. Gülce'nin katılacağı organizasyon hangi üniversitededir?

$$
\begin{aligned}
& \text { a) Gazi Üniversitesi } \\
& \text { b) Konya Karatay Üniversitesi } \\
& \text { c) Bülent Ecevit Üniversitesi } \\
& \text { d) Gaziantep Üniversitesi }
\end{aligned}
$$

Şekil 3. Gazi Üniversitesi yabancılar için Türkçe ders kitabı dinleme 3 görseli, 1. Ünite, Sayfa 15: "Yardım Projesi”

Dinleme etkinliği incelendiğinde metinde Fatma ve Gülce isimli iki bayan arkadaşın bir yardım projesi hakkındaki diyaloğunun ele alındığı görülmektedir. Etkinlikte toplam 3 sorudan oluşan çoktan seçmeli soru tipi kullanılmıştır. Metinde ağırlıklı olarak şimdiki zamana yer verilmiştir. Avrupa Dil Portfolyosu'na göre B1 seviyesi ile uyumludur. Metindeki kelimeler B1 seviyesi için uygun görülebilir. Dinleme metnini iki bayan seslendirmektedir. Metin bir görsel ile desteklenmiştir. Ancak görselin metnin içeriği ile kesinlikle ilgisi bulunmamaktadır. Metinde görme engelliler için kitap seslendirme projesinden bahsedilmektedir. Fakat görselde iki mutsuz bayan görüntüsüne yer verilmiştir. Bu da bahsi geçen projenin gereksiz ve faydasız olduğu izlenimini uyandırmaktadır. Gönüllülük esas alınarak yapılacak bir yardım projesinden bahsedilmesine rağmen görselde gönülsüz iki bayana yer verilmiştir. Metnin içeriğinde iki arkadaş sohbet ederken, görselde iki arkadaşın sohbeti değil, ders çalışan mutsuz iki bayana yer verilmesi metin içeriğinin görsel uyumu açısından sorunludur. 
Examination of Gazi University B1 level textbook listening department in teaching Turkish as a foreign language / M. Gün; M. Bakırdöğen (pp. 59-79)

\section{Dinleme 4}
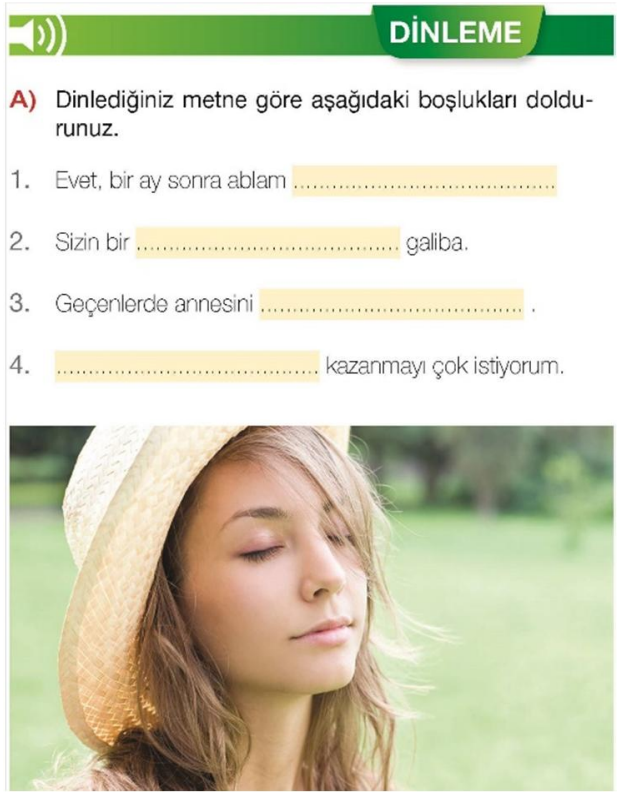

B) Așağıdaki soruları dinlediğiniz diyaloğa göre cevaplayınIz.

1. Dinlediğiniz diyalogda geçen "kısmet" kelimesi neyin karşılığı olarak kullanılmıs olabilir?

$\begin{array}{ll}\text { a) para } & \text { b) ev } \\ \text { c) kardes } & \text { d) sevgili }\end{array}$

2. Așağıdaki ifadelerden hangisi doğrudur? $\begin{array}{ll}\text { a) dilek istemek } & \text { b) dilek tutmak }\end{array}$ c) dilek yapmak d) dilek etmek

3. "Kalpten istemek" deyiminin anlamı nedir? a) az istemek

b) bașkasindan istemek c) çok fazla istemek d) hiç istememek

Şekil 4. Gazi Üniversitesi yabancılar için Türkçe ders kitabı dinleme 4 görseli, 1. Ünite, Sayfa 19: "Fal Keyfi”

Dinleme metninde tema olarak Naciye abla isimli bir bayanın Elifin kahve falına bakması ve kahve fincanındaki şekillere yorum yapmasına yer verilmiştir. Etkinlik iki grupta ele alınmıştır. İlk olarak dört adet boşluk doldurma vardır. İkinci olarak üç adet çoktan seçmeli test vardır. Metnin dil bilgisi yapısı Avrupa Dil Portfolyosu'na göre B1 seviyesi için uygundur. Metnin kelimeleri ise öğrenci seviyesine eş değerdir. Etkinlikte metin görselle desteklenmektedir. Ancak bu görsel içerikle doğrudan değil dolaylı olarak ilgilidir.

\section{Dinleme 5}

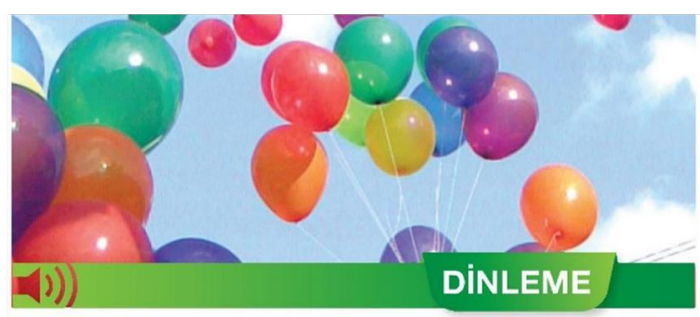

A) Dinlediğiniz metne göre ișaretleyiniz. (Doğru: $\checkmark$, Yanlıș: $\times$ )

Renkler, insanların psikolojisini ve duygularıาı etkilemez.

Kurmıı, turuncu ve sarı gibi sıcak renkler insanda solunumu hızlandirrr.

Hamburgerci veya pizzacilarnn duvarlar kahverengidir.

Insanlar en çok kımmızııı sevmektedir.

Cocuklar koyu renkleri tercih eder.

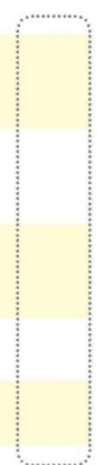


Şekil 5. Gazi Üniversitesi yabancılar için Türkçe ders kitabı dinleme 5 görseli, 2. Ünite, Sayfa 25: "Psikolojide Renklerin Etkisi”

Dinleme etkinliğinde konu olarak renklerin insan hayatını ve duygularını önemli derecede etkilediği, ayrıca renklerin insan psikolojisine etkileri ele alınmıştır. Metinde ana renkler olan kırmızı, turuncu, sarı, mavi vb renkler vardır. Etkinlikte doğru ve yanlış soru tipi kullanılmıştır. Etkinlikte toplam beş adet soru vardır. Metin dil bilgisi yapısı genel olarak Avrupa Dil Portfolyosu'na göre B1 seviyesine uygundur. Ancak bazı cümlelerde edilgen yapılı fiiller kullanıldığı gözlemlenmiştir. Fiillerde çatı konusu Avrupa Dil Portfolyosu'na göre B2'de yer almaktadır. Etkinlikteki kelime yapısı ise seviyeye son derece uygundur. Metnin neredeyse tamamı birçok öğrencinin A1 düzeyinde duyduğu kelimelerden oluşmaktadır. Etkinlik her renkten balona yer verilen bir görselle desteklenmiştir.

\section{Dinleme 6}

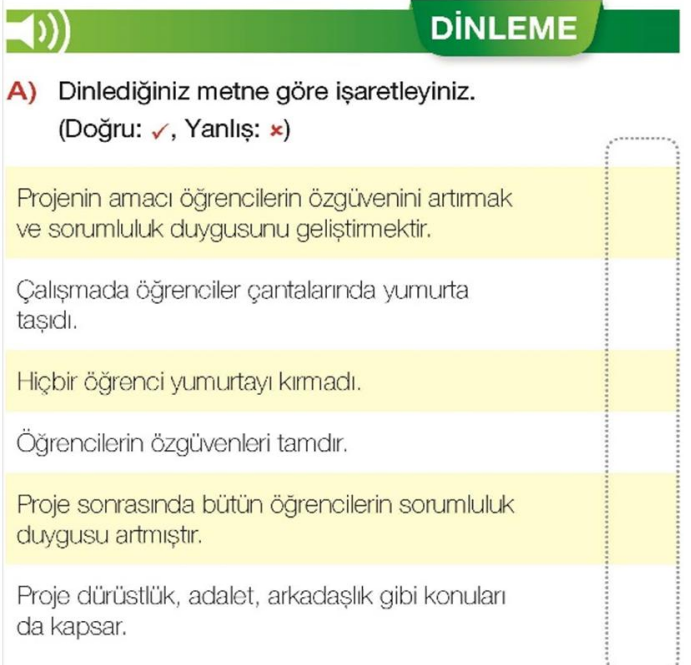

Şekil 6. Gazi Üniversitesi yabancılar için Türkçe ders kitabı dinleme 6 görseli, 2. Ünite, Sayfa 29: “Adam Olacak Çocuklar"

Dinleme metninde bir okulda hem öğrencilerin özgüvenlerini artırmak hem de sorumluluk duygusunu geliştirmek için başlatılan bir uygulamadan bahsedilmektedir. Bu dinleme, karakter eğitimi projesi ile ilgilidir. Etkinlikte doğru ve yanlış soru tipi kullanılmıştır. Soru sayısı altıdır. Metin dil bilgisi yapısı Avrupa Dil Portfolyosu'na göre B1 seviyesi için uygundur. Etkinlikte kullanılan kelimeler de seviye ile uyumludur. Dinleme metnini bir erkek seslendirmektedir. Dinleme etkinliğinde görsele yer verilmemiştir. Metnin içerik yapısı nedeniyle görsel kullanılmamış olması kabul edilebilir. 
Examination of Gazi University B1 level textbook listening department in teaching Turkish as a foreign language / M. Gün; M. Bakırdöğen (pp. 59-79)

\section{Dinleme 7}

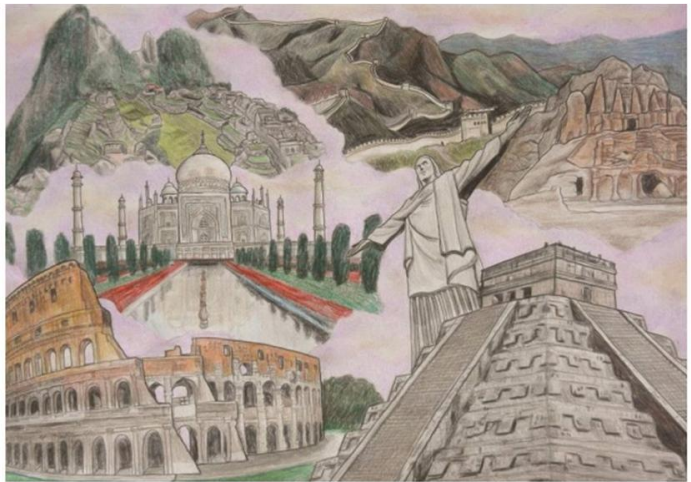

J))

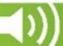

\section{DINLEME}

A) Dinlediğiniz metne göre ișaretleyiniz. (Doğru: $\checkmark$, Yanlıș: x)

Günümüzde geçerli olan "Dünyanın Yed Harikası" listosi, M.Ö. 5. yüzyılda son șeklini aldı.

Keops Piramidi de diğer yapillar gibi yok olmuștur.

Şekil 7. Gazi Üniversitesi yabancılar için Türkçe ders kitabı dinleme 7 görseli, 2. Ünite, Sayfa 33: "Dünyanın yedi harikası"

Dinleme metninde konu olarak tamamı insanoğlu tarafından inşa edilmiş, olağanüstü yapıtlar olan dünyanın yedi harikası ele alınmıştır. Dinlemede dünyanın yedi harikası olan Keops Piramidi’ne, Babil'in Asma Bahçeleri’ne, Artemis Tapınağı'na vb. değinilerek özellikleri verilmektedir. Etkinlikte doğru ve yanlış soru tipi kullanılmıştır. Etkinlikteki toplam soru sayısı ondur. Metinde kullanılan dil bilgisi yapısı ve kullanılan kelimeler Avrupa Dil Portfolyosu'na göre B1 seviyesi ile uyumludur. Etkinlikte görsel kullanılmıştır. Kullanılan görsel dinleme metni ile uyumludur. Fakat görsel boyut olarak küçüktür ve görselde kullanılan renklerin kalitesi yetersizdir. Bu sebeple görsel çok da iyi anlaşılamamaktadır.

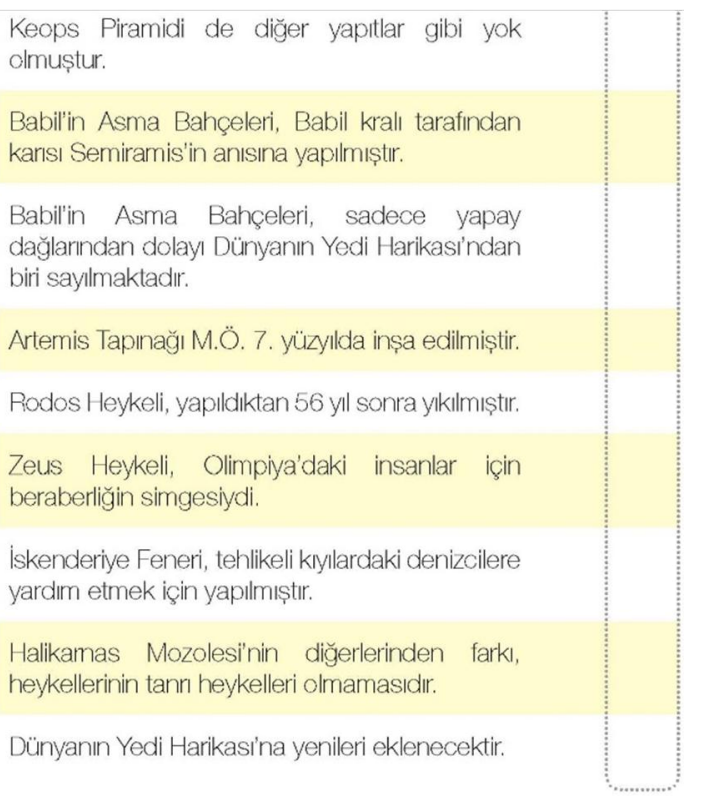

lskenderiye Feneri, tehlikeli kıylardaki denizcilere yardım etmek için yapılmıștır.

Mozolesi'nin diğerlerinden farkı,

Dünyanın Yedi Harikasina yenileri eklenecektir. 


\section{Dinleme 8}

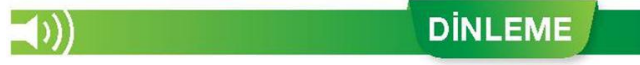

A) Metni dinleyiniz ve așağıdaki soruları cevaplayınız.

1. Ayșe Hanım alıșveriș yapacak parayı nereden buluyor?
a) Eșinden gizli bir iște çalıșyor.
b) Arkadașlarından borç alyor.
c) Yaptığl el ișlerini satıyor
d) Eșinden allyor.

2. Așağıdakilerden hangisi Ayșe Hanım'ın alıșveriș ürünlerinden değildir?
a) hırka
b) çizme
c) kazak
d) ayakkabı

4. Metinle ilgili așağıdaki cümlelerden hangisi yanlıștır?
a) Ayșe Hanım evin bütün gelir gider ișlerinden sorumlu- dur.
b) Ayșe Hanım maddi olarak eșine destek olmaktadır.
c) Aile, borçları yüzünden ekonomik olarak sıkıntıdadır.
d) Ayșe Hanım yaptığı el ișlerini satarak para kazanıyor.

5. Așağıdakilerden hangisi metinde geçen deyimlerden biri değildir?
a) kara kara düșünmek
b) rahata ermek
c) çorbada tuzu bulunmak
d) ayağını yorganına göre uzatmak

3. Metne göre "dișini sıkmak" deyiminin anlamı ne olabilir?
a) dișlerini birbirine bastırmak
b) sıkıntiya katlanmak
c) para biriktirmek
d) tasarruflu olmak
e) minnet

Şekil 8. Gazi Üniversitesi yabancılar için Türkçe ders kitabı dinleme 8 görseli, 2. Ünite, Sayfa 39: “Ev Ekonomisi”

Dinleme etkinliğinde konu olarak Ayşe Hanım’ın ev ekonomisi için yaptığı tasarruf ve ev ekonomisine yaptığı katkı ele alınmıştır. Etkinlikte, dinleyiniz ve aşağıdaki soruları cevaplayınız şeklinde beş adet çoktan seçmeli soruya yer verilmiştir. Etkinlik metni Avrupa Dil Portfolyosu'na göre B1 dil bilgisi kurallarına uygundur. Bu dinleme metninde deyim ve atasözüne yer verilmiştir. Örneğin dişini sıkmak, ayağını yorganına göre uzatmak gibi. Bu ve benzeri söz kalıplarını ilk kez duyan öğrenciler için dinleme metni öğrencinin kaygı düzeyini artırabilir ya da öğrencilerin metnin sorularına yanlış cevap vermelerine neden olabilir. Bu bağlamda dinleme etkinliğini yapmadan önce öğretici tarafından metnin sorularına ve içeriğine yönelik gerekli açıklamalar yerinde olacaktır. Dinleme metnini bir bayan ve bir erkek seslendirmektedir. Bayan oldukça net, telaffuzu anlaşılır seslendirmekle beraber, erkek için aynı durun geçerli değildir. Bu durum metnin anlaşılırlığını zorlaştırmaktadır. Metne uygun görsel kullanılmamıştır. Hâlbuki metin içerisinde dikiş, nakış, çeyiz gibi Türk kültürünü anlatan kavramlar geçmektedir. Bu kavramlara ait görseller ile metin desteklenebilir ve böylece görseller ile kültür aktarımı gerçekleşebilir. Öğrenci bu görseller ile dinlemeyi daha iyi anlamlandırabilir ve dinlemenin anlaşılırlığını daha da artabilir. 
Examination of Gazi University B1 level textbook listening department in teaching Turkish as a foreign language / M. Gün; M. Bakırdöğen (pp. 59-79)

\section{Dinleme 9}

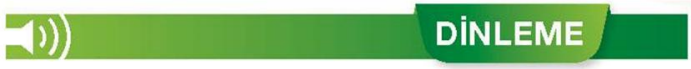

A) Așağıdaki soruları dinlediğiniz metne göre cevaplayınız.

1. Köșe yazarı, kitabevine niçin geliyor?

a) yeni kitaplar almak için b) söyleși yapmak için

c) imza günü için d) șiir kitabını tanıtmak için

2. Metindeki kiși niçin iștahsız?
a) hasta olduğu için
b) heyecanlı olduğu için
c) șișman olduğu için
d) üzüldüğü için

3. Danıșmadaki genç kız niçin üzülüyor?

a) müșterisi imza gününü kaçırdığı için

b) müșterisinin aradığı kitap kalmadığı için

c) ișe geç kaldığı için

d) ilan tarihini yanlıș söylediği için

B) Metni tekrar dinleyiniz ve așağıdaki boșlukları doldurunuz.

1. Kitapların üzerinde ertesi gün, ............... düșünüp ivice heyecanlandim

2. Kendime en çok yakıșan kiyafetimi ............... seçtim.

3. Büyük bir kalabalıkla karșllașacağımı düșünürken

Şekil 9. Gazi Üniversitesi Yabancılar İçin Türkçe Ders Kitabı dinleme 9 görseli, 3. Ünite, Sayfa 45: “İmza Günü”

Metinde içerik olarak ünlü bir köşe yazarına hayran olan bir kişinin, yazarın imza gününün tarihini yanlış okuması ve yaşadığı hayal kırıklığı ele alınmıştır. Etkinlik iki grupta ele alınmıştır. Birinci bölümde üç adet çoktan seçmeli soru tipi vardır. İkinci bölümde üç adet boşluk doldurma soru tipi vardır. Metnin dil bilgisi yapısı Avrupa Dil Portfolyosu'na göre B1 seviyesi için uygun değildir. Metnin genelinde fiilimsi dil bilgisi yapısı kullanılmıştır. Ancak fiilimsi Avrupa Dil Portfolyosu'na göre B2'de yer almaktadır. Kullanılan kelimeler öğrenci seviyesine uygun olup, aynı şey dil bilgisi için geçerli değildir. Metni seslendiren net ve anlaşılır telaffuz kullanmıştır. Dinleme etkinliğinde metni destekler bir görsel kullanılmamıştır. Ancak öğrencinin metin içerisinde geçen köşe yazarı ve imza günü gibi kavramları daha iyi anlamlandırması için metni destekler bir görsel kullanımı yerinde ve uygun olabilir.

\section{Dinleme 10}

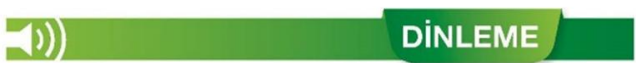

A) Așağıdaki soruları dinlediğiniz metne göre cevaplayıniz.

1. Kitap ne hakkındadır?

$\begin{array}{ll}\text { a) siyaset } & \text { b) tarih } \\ \text { c) bilim } & \text { d) kișisel gelișim }\end{array}$

2. Metne göre artık hangi kavramları hayatımızdan çıkaracağız?

a) bașarısızl|k, mutsuzluk

b) huzursuzluk, çaresizlik

c) umutsuzluk, çaresizlik

d) bașarısılik, çaresizlik

3. Metne göre bizi zihinsel açıdan yoran nedir?

a) çalıșma koșulları, başarısızlık

b) özgüven problemi, sayglsizlik

c) sevgisizlik, özgüven problemi

d) yoğun çallșma temposu, özgüven problemi
B) Metni tekrar dinleyiniz ve așağıdaki boșlukları doldurunuz.

Sevgili ........

Sizler

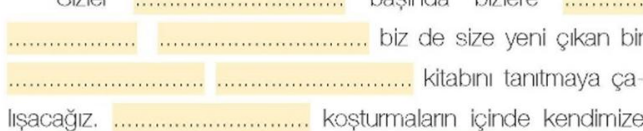

ıșacağız. ............................. koşturmalann içinde kendimize

hiç .......................... ayıramadığımı, ......................... ą̧

brraktığımı șu dönemde; ........................ ediyoruz ki bu kitap,

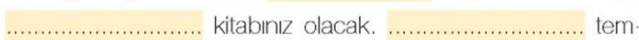

posu, iște ............................ endișesi,

problemi bizi ............................ yormaktadir ve bu da tüm ha-

yatımiza .............................

İște bu kitapla, ........................... Özgüveninizi

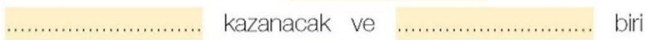

olacaksinı. …....................., ....................... gibi

kavramları artik .......................... çוkaracaksını. Unut-

mayın ........................ da ........................ ve onu

gerekir. Hemen size en yakın kitap̧̧ıya ve ........................... doyurun!

Şekil 1o. Gazi Üniversitesi yabancılar için Türkçe ders kitabı dinleme 10 görseli, 3. Ünite, Sayfa 49: "Başucu Kitabı" 
Metinde içerik olarak yeni çıkan bir kişisel gelişim kitabının bir radyo programında dinleyicilere tanıtımı yapılmaktadır. Etkinlikte iki farklı soru tipi kullanılmaktadır. Birinci bölümde üç adet çoktan seçmeli soru vardır. İkinci olarak dinleyiniz ve aşağıdaki boşlukları doldurunuz şeklinde boşluk doldurma soru tipi vardır. Metinde kullanılan dil bilgisi yapısı ve kullanılan kelimeler genelde Avrupa Dil Portfolyosu'na göre B1 seviyesi ile uyumludur. Seslendiren dinleme metnini net ve anlaşllır bir şekilde seslendirmiştir. Dinleme metninde görsel kullanılmamıştır. Metnin içerik yapısı nedeniyle görsel kullanılmamış olması kabul edilebilir.

\section{Dinleme 11}

J))

\section{DINLEME}

A) Așağıdaki soruları dinlediğiniz metne göre cevaplayınız.

1. Așağıdaki ülkelerden hangisi farklı evleriyle anılmamıștır?

$\begin{array}{ll}\text { a) Yunanistan } & \text { b) Portekiz } \\ \text { c) Rusya } & \text { d) Kore }\end{array}$

2. Kendisini kral gibi hissetmek isteyenler için nasıl evler tercih ediyorlar?

a) vagon evler

b) kale burcu șeklinde evler

c) tropik ever

d) yüzen evler

3. Insanlar niçin tropik evlerde kalmayı tercih ediyorlar?

a) insanlann tatil algllan değiștiği için

b) evler sahile yakın olduğu için

c) evlerin haftalık kirası ucuz olduğu için

d) evler konforlu olduğu için

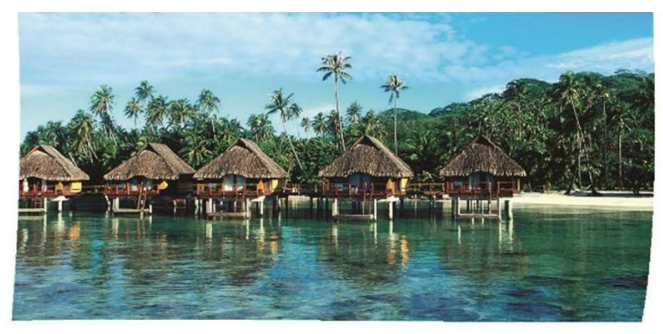

B) Așağıdaki cümleleri metne göre işaretleyiniz. (Doğru: $\checkmark$, Yanlıș: $x$ )

Sazlardan yapılan evler oldukça konforludur:

Yel değirmeni șeklindeki evlerin haftallk kirası yüksektir.

Denizi sevenler, yüzen evlerde kalabilir.

Vagon evler taștan yapılmaktadır.

Tropik ever Portekiz' dedir.

Şekil 11. Gazi Üniversitesi yabancılar için Türkçe ders kitabı dinleme 11 görseli, 3. Ünite, Sayfa 53: "Tatil İlanları"

Metinde içerik olarak gazete okurken tatil ilanları dikkatini çeken bir kişinin sıra dışı tatil mekanları hakkında bilgi vermesi ele alınmıştır. Etkinlikte iki farklı soru tipi kullanılmaktadır. Birinci bölümde üç adet çoktan seçmeli soru tipi vardır. İkinci bölümde ikinci bölümde doğru yanlış soru tipi vardır. Metnin genelinde fiillerde çatı konusu olan edilgen dil bilgisi yapısı kullanılmıştır. Ancak fiillerde çatı Avrupa Dil Portfolyosu'na göre B2'de yer almaktadır. Kullanılan kelimeler öğrenci seviyesine genel olarak uygundur ses kaydının bazı yerleri seslendirenin ses tonundan kaynaklı anlaşlırlıktan uzaktır. Metinde dinlemenin içeriğine uygun bir görsel kullanılmaktadır. Ancak bu görsel yetersizdir. Çünkü metnin içeriğinde çok sayıda tatil mekanı anlatılmaktadır. Görsel olarak dinleme metninde anlatılan mekanlarla ilgili daha fazla görsel kullanımı metnin anlaşılırlığını artırabilir. 
Examination of Gazi University B1 level textbook listening department in teaching Turkish as a foreign language / M. Gün; M. Bakırdöğen (pp. 59-79)

\section{Dinleme 12}

\section{ग) DINLEME}

A) Așağıdaki soruları dinlediğiniz diyaloğa göre cevaplayını.

1. Diyalogda küresel ısınmanın temel nedeni olarak ne ileri sürülmektedir?
a) sanayi ükkeleri
b) buzullarin erimesi
c) gazlarin sera etkisi
d) sicakllklann artmasi

2. Așağıdakilerden hangisi küresel ısınmanın olası sonuçlarından biri değildir?

$\begin{array}{lll}\text { a) buzullarn erimesi } & \text { b) nüfusun azalması }\end{array}$

c) canı türlerinin azalması d) iklimin değișmesi
B) Așağıdaki cümleleri metne göre ișaretleyiniz. (Doğru: $\checkmark$, Yanlıș: $x$ )

Küresel ısınmanın sonucunda denizlerde su seviyesi yükselecektir.

Gelișmemiș ülkeler, küresel ısınma konusunda bilinçsiz davranmaktadır.

Buzulların erime sebebi, sera etkisi yapan gazların atmosfere bırakılmasidır.

10 yll içinde birçok canlı türü yok olabilir.

Kitaplar ve belgesellerde küresel ısınmanın sonuçları anlatımaktadir.

Şekil 12. Gazi Üniversitesi yabancılar için Türkçe ders kitabı dinleme 12 görseli, 3. Ünite, Sayfa 57: "Küresel Isınma"

Metinde içerik olarak Sezen ve Emir isimli iki arkadaşın küresel ısınma hakkındaki sohbetleri ele alınmıştır. Metinde genel olarak küresel ısınmanın sebep ve sonuçları üzerinde durulmuştur. Etkinlikte iki farklı soru tipi kullanılmaktadır. Birinci olarak iki adet çoktan seçmeli soru vardır. İkinci olarak doğru yanlış soru tipi vardır. Etkinlikte toplam beş adet soru vardır. Metinde fiillerde çatı konusu olan edilgen dil bilgisi yapısı kullanılmıştır. Ancak fiillerde çatı Avrupa Dil Portfolyosu'na göre B2'de yer almaktadır. Metnin genelinden öğrenci bu fiil yapısını anlayabilir. Kullanılan kelimeler öğrenci seviyesine genel olarak uygundur. Dinleme metnini bir bayan ve bir erkek seslendirmektedir. Erkeğin seslendirmesi net ve anlaşlırken, bayanın seslendirmesi hızlıdır. Bu durum metnin anlaşılırlığını zorlaştırmaktadır. Dinleme etkinliğinde Küresel ısınmayı destekler bir görsel kullanılmamıştır. Bu durum da öğrencinin metni anlamasını ve algılamasını olumsuz etkileyebilir. Metinde küresel ısınmanın sebep veya sonucunu anlatan bir görsel kullanımı uygun görülebilir.

\section{Dinleme 13}

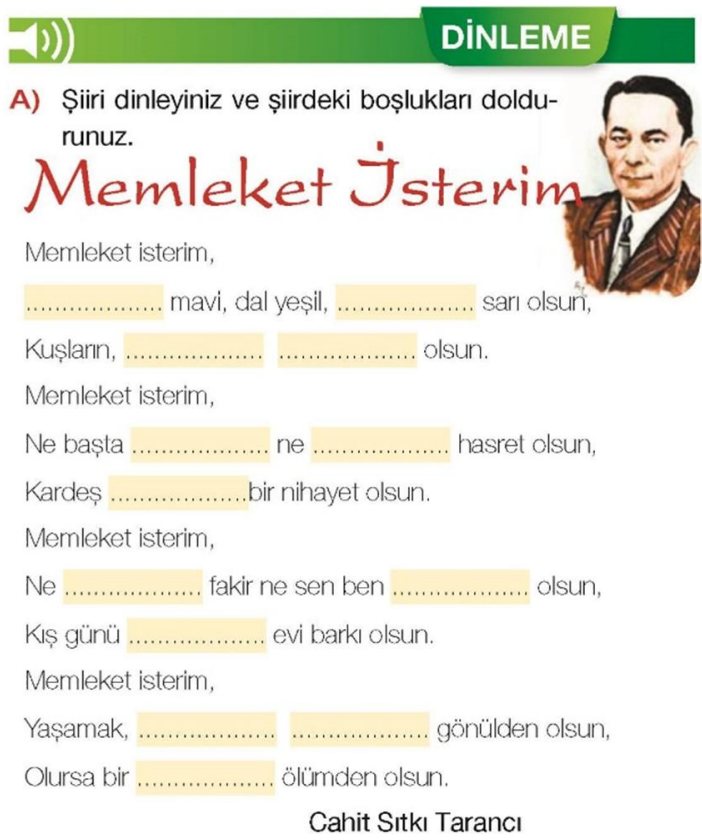


Şekil 13. Gazi Üniversitesi yabancılar için Türkçe ders kitabı dinleme 13 görseli, 4. Ünite, Sayfa 63: "Memleket Isterim"

Metinde içerik olarak Cahit Sıtkı Tarancı'nın Memleket İsterim şiiri ele alınmıştır. Şiiri dinleyin ve boşlukları doldurun şeklinde soru tipi kullanılmıştır. Metin dil bilgisi yapısı genel olarak Avrupa Dil Portfolyosu'na göre B1 seviyesine uygundur. Etkinlikte kullanılan kelimeler ise seviye ile uyumludur. Seslendirme oldukça net ve anlaşılırdır. Dinleme etkinliğinde Cahit Sıtkı Tarancı'nın görseline yer verilmiştir. Görsel metni destekler niteliktedir.

\section{Dinleme 14}

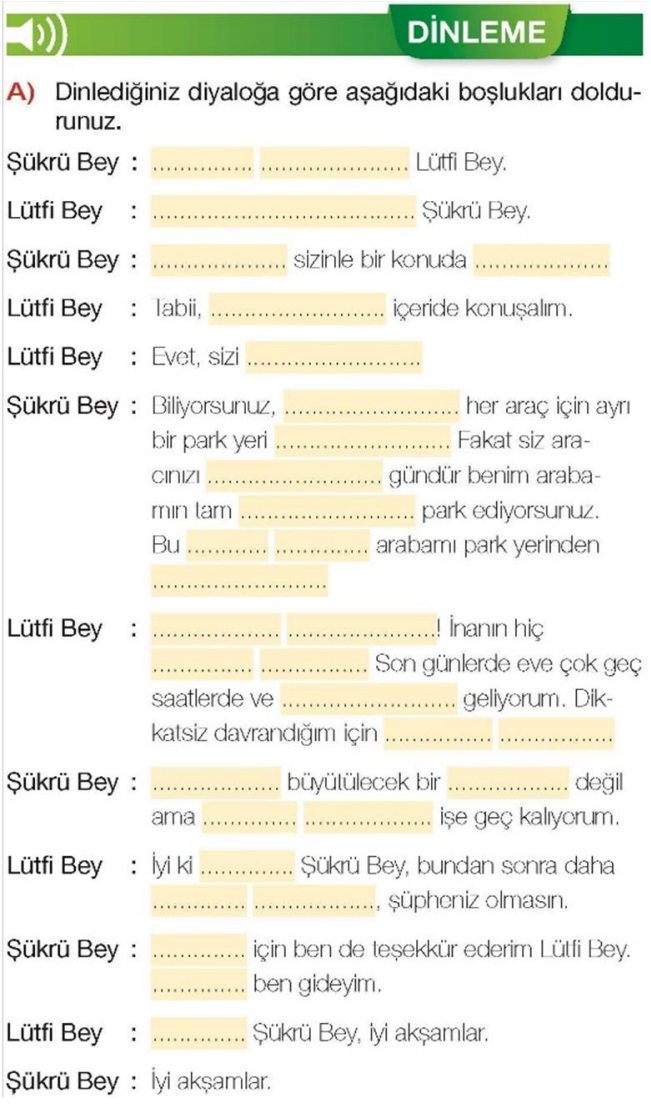

B) Dinlediğiniz diyaloğa göre ișaretleyiniz. (Doğru: $\checkmark$, Yanlıș: $x$ )

Lüti ve Ș̈̈krü Beyler aynı apartmanda otururlar

Lütfi Bey konușmak için Șükü Bey'in evine gider

Lüti Bey arabasını Șükrü Bey'in arabasının arkasina park eder.

Șükrü Bey son günlerde aracin yanllş yere park etmektedir.

Apartmanın otoparkında her araç için bir yer ayrimmıștır.

Şekil 14. Gazi Üniversitesi yabancılar için Türkçe ders kitabı dinleme 14 görseli, 4. Ünite, Sayfa 67: "İki Komşu”

Metinde içerik olarak iki komşu olan Lütfi Bey ve Şükrü Bey arasında geçen bir diyalog ele alınmıştır. Metinde arabasını yanlış yere park eden Lütfi Bey’i, Şükrü Bey kibar bir dille uyarmaktadır. Etkinlik iki grupta ele alınmıştır. İlk olarak dinleyiniz ve diyaloğa göre göre boşlukları doldurunuz şeklinde soru tipi vardır. İkinci olarak doğru yanlış soru tipi vardır. Toplamda beş adet soru vardır. Metinde kullanılan dil bilgisi yapısı ve kullanılan kelimeler genelde Avrupa Dil Portfolyosu'na göre B1 seviyesi ile uyumludur. İki komşu adlı dinleme metninde her iki komşunun da ses tonlarının benzemesi metnin anlaşılırlığını zorlaştırmaktadır. Dinleme metninde görsel kullanılmamıştır. Metnin içerik yapısı nedeniyle görsel kullanılmamış olması kabul edilebilir. 
Examination of Gazi University B1 level textbook listening department in teaching Turkish as a foreign language / M. Gün; M. Bakırdöğen (pp. 59-79)

\section{Dinleme 15}

D) DINLEME

A) Așağıdaki soruları dinlediğiniz diyaloğa göre cevaplayınIz.

1. Așağıdakilerden hangisi çocuğun elindeki postalardan biri değildir?

$\begin{array}{ll}\text { a) sarı bir zarf } & \text { b) elektrik faturası } \\ \text { c) telefon faturası } & \text { d) su faturası }\end{array}$

2. Mektubun üzerinde kimin adı yazıyor?
a) çocuğun
b) annenin
c) babanin
d) apartman yöneticisinin

3. Mektup nereden/kimden geliyor?
a) apartman yönetiminden
b) bankadan
c) adliyeder
d) okul yönetiminden

B) Așağıdaki cümleleri metne göre ișaretleyiniz. (Doğru: $\checkmark$, Yanlıș: $x$ )

Posta kutusundaki zarf anneyi șașırtı.
Annenin beș aylık aidat borcu vardır.
Anne, aidatları düzenli olarak yatırmıștır.
Oğul, yönetimle görüșmeye gitti.
Problemi çözmek için babalarını beklemeye
karar verdiler.

C) Așağıdaki cümleyi dinlediğiniz diyaloğa göre tamamlayınız.

"Diyalogdaki anne, zarfi oğluna açtrryor çünkü

Şekil 15. Gazi Üniversitesi yabancılar için Türkçe ders kitabı dinleme 15 görseli, 4. Ünite, Sayfa 71: "Bu İşte Bir Yanlışlık Var"

Metinde içerik olarak bir anne ve oğul arasında geçen bir diyalog ele alınmıştır. Dinleme metninde, posta kutusuna gelenler arasında anne adına gelen bir sarı zarf ve annenin apartman aidatını ödemediğine dair uyarı yazısı üzerinde durulmaktadır. Dinleme etkinliğinde üç farklı soru tipi kullanılmıştır. İlk olarak üç sorudan oluşan çoktan seçmeli soru tipi. İkinci olarak beş sorudan oluşan doğru yanlış soru tipi. Üçüncü olarak da bir cümle verip dinlediğiniz diyaloğa göre tamamlayınız şeklinde soru tipi. Metin dil bilgisi yapısı genel olarak Avrupa Dil Portfolyosu'na göre B1 seviyesine uygun değildir. Çünkü bazı fiilimsilerin kullanıldığı gözlemlenmiştir. Fiilimsiler konusu Avrupa Dil Portfolyosu'na göre B2'de yer almaktadır. Etkinlikteki kelime yapısı ise seviyeye oldukça uygundur. Dinleme metninde görsel kullanılmamıştır. Metnin içerik yapısı nedeniyle görsel kullanılmamış olması kabul edilebilir.

\section{Dinleme 16}

\section{D) DINLEME}

A) Așağıdaki soruları dinlediğiniz diyaloğa göre cevaplayınız.

1. Müșterinin mesleği nedir?

$$
\begin{array}{ll}
\text { a) bilgisayar mühendisliği } & \text { b) inșaat mühendisliği } \\
\text { c) makine mühendisliği } & \text { d) endüstri mühendisliği }
\end{array}
$$

2. Așağıdakilerden hangisi, müșterinin aradığı bilgisayarın özelliklerinden biri değildir?
a) hızı
b) hafif
c) 1500-2000 lira arasinda
d) servis ağı geniș

3. Aden ve Madalyon markaları arasındaki fark nedir?
a) servis ağ|
b) teknik özelliker

c) ağırlık

d) $h \mid z$
B) Așağıdaki tabloyu, dinlediğiniz diyaloğa göre doldurunuz. Modellerin özelliklerini yazınız.

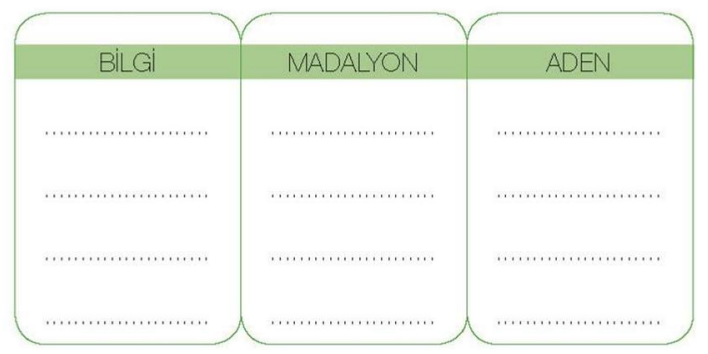


Şekil 16. Gazi Üniversitesi yabancılar için Türkçe ders kitabı dinleme 16 görseli, 4. Ünite, Sayfa 75: "Bilgisayar Alırken"

Dinleme metninde içerik olarak bilgisayar alırken nelere dikkat edilmesi gerektiğine dair bir satıcı ve müşteri arasında geçen diyalog ele alınmıştır. Etkinlikte iki farklı soru tipi kullanılmıştır. Birinci olarak üç çoktan seçmeli soru, ikinci olarak da dinlediğiniz diyaloğa göre doldurunuz şeklindeki soru tipi kullanılmıştır. Metin dil bilgisi yapısı Avrupa Dil Portfolyosu'na göre genel olarak B1 seviyesine uygundur. Ancak fiilimsilerin kullanıldığ 1 gözlemlenmiştir. Fiilimsiler konusu Avrupa Dil Portfolyosu'na göre B2'de yer almaktadır. Etkinlikteki kelime yapısı ise seviyeye uygundur. Dinlemenin hızı Avrupa Dil Portfolyosu'na göre seviyeye uygun değildir. Dinleme metninde görsel kullanılmamıştır. Bilgisayar genellikle çoğu insan tarafından bilinen bir kavram olduğu için metnin görselle desteklenmemesi kabul edilebilir.

\section{Dinleme 17}

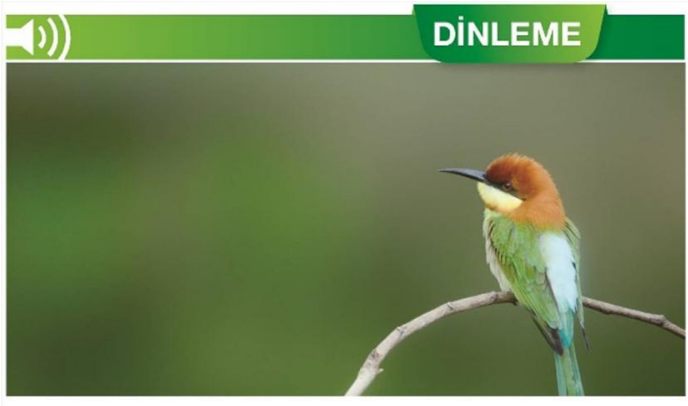

A) Metni dinleyiniz ve bilgi tablosunu metne göre doldurunuz.

\begin{tabular}{||l||l||l||}
\hline & Avcl & Kuș \\
\hline \hline Tuzak kurar. & & \\
\hline \hline Tuzağa düșer. & & \\
\hline \hline Kendini iyi niyetli olarak tanitir. & & \\
\hline \hline Buğdaylardan ikram eder. & & \\
\hline \hline Tedbirsiz davranır. & & \\
\hline \hline Tuzağa düștükten sonra ağlar. & & \\
\hline \hline Nasihat eder. & & \\
\hline \hline
\end{tabular}

B) Așağıdaki soruları dinlediğiniz metne göre cevaplayınız.

1. Hikâyedeki avcı nasıl birisidir?

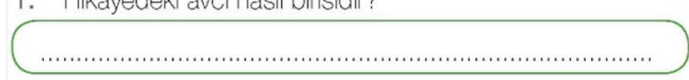

2. Hikâyedeki kuș nasıldır?

3. Kus neden bağırip ağlamaya bașlamıștır?

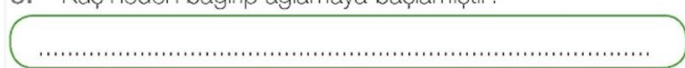

4. Avcı neden çalların arkasına saklanmıștır?

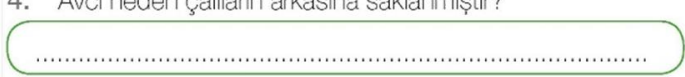

5. Hikâyede avcının verdiği mesaj nedir?

Şekil 17. Gazi Üniversitesi yabancılar için Türkçe ders kitabı dinleme 17 görseli, 5. Ünite, Sayfa 81: "Avcı İle Küçük Kuş"

Metinde içerik olarak küçük bir kuş ve avcı arasında geçen hikaye işlenmektedir. Dinleme etkinliğinde iki farklı soru tipi kullanılmıştır. İlk olarak bir tabloda hikaye ile ilgili yedi adet bilgi verilmiştir. Bu bilgilerin hikaye kahramanlarıyla eşleştirilmesi istenmiştir. İkinci olarak da beş adet açık uçlu soru tipi kullanılmıştır. Metinde dil bilgisi yapısı olarak genellikle fiilimsilere (saklanarak, söylenen, ağlayıp vb.) yer verilmiştir. Ancak fiilimsiler konusu Avrupa Dil Portfolyosu'na göre B2'de yer almaktadır. Etkinlikteki kelime yapısı ise seviyeye oldukça uygundur. Dinleme metninde görsel kullanılmıştır. Ancak bu görsel hikayeyi destekler nitelikte değildir. Görsele ek olarak bir avcının da resmedilmesi metin içeriğiyle görsel uyumu açısından yerinde olabilir. 
Examination of Gazi University B1 level textbook listening department in teaching Turkish as a foreign language / M. Gün; M. Bakırdöğen (pp. 59-79)

\section{Dinleme 18}

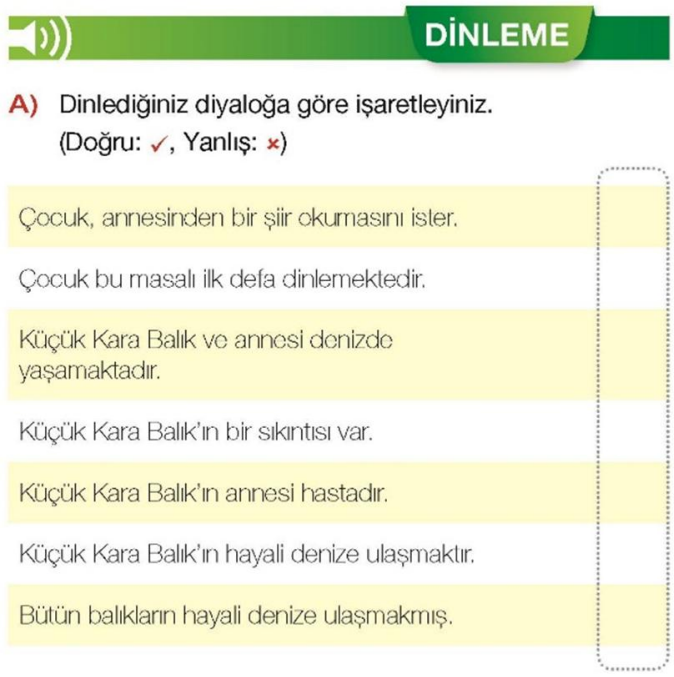

Şekil 18. Gazi Üniversitesi yabancılar için Türkçe ders kitabı dinleme 18 görseli, 5. Ünite, Sayfa 85: "Bana Bir Masal Anlat”

Metinde içerik olarak çocuğunun uyuması için, bir annenin anlattığı masal ele alınmıştır. Doğru yanlış soru tipi kullanılmıştır. Etkinlikte soru vardır. Metinde dil bilgisi yapısı olarak genellikle fiilimsilere (zannedip, ayrılıp, ulaşıp vb.) yer verilmiştir. Ancak fiilimsiler konusu Avrupa Dil Portfolyosu'na göre B2'de yer almaktadır. Etkinlikteki kelime yapısı ise seviyeye uygundur. Dinleme etkinliğinde görsel kullanılmamaktadır. Hâlbuki dinleme metninde annenin anlattığı masalı destekler bir küçük karabalık görseli kullanımı yerinde ve uygun olabilir.

\section{Dinleme 19}

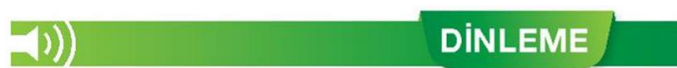

A) Așağıdaki soruları dinlediğiniz metne göre cevaplaylnIz.

1. Așağıdakilerden hangisi Ters Lale çiçeğinin en çok kullanılan diğer adıdır?
a) Ağlayan Gelin çiçeği
b) Hakkâri çiçeği
c) Isa çiçeği
d) Asurî çiçeği

2. Ters Lale, Türkiye'nin neresinde yetișmektedir?
a) Hakkâri
b) Sirnak
c) Mardin
d) Hatay

3. Bu çiçekle ilgili așağıdakilerden hangisi söylenemez?
a) Ters Lale çiçeği çok yaygın görülen bir çiçektir.
b) Ters Lale çiçeği çok değerli bir çiçektir.
c) Ters Lale çiçeğinin yapraklarından su damlamaktadır.
d) Ters Lale çiçeği hakkında dinî bir inanıș vardır.

B) Așağıdaki cümleleri metne göre ișaretleyiniz. (Doğru: $\checkmark$, Yanlıș: $x$ )

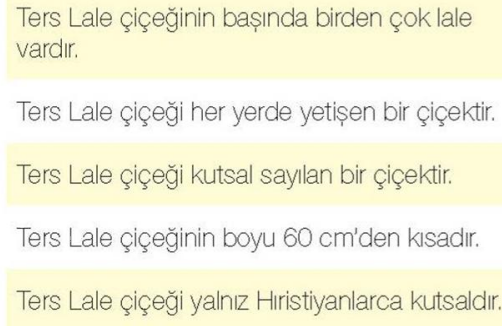

Şekil 19. Gazi Üniversitesi yabancılar için Türkçe ders kitabı dinleme 19 görseli, 5. Ünite, Sayfa 89: "Ters Lale"

Metinde içerik olarak Hakkâri'nin dağlarının yüksek kesimlerinde yetişen, dünyanın en nadide çiçeklerinden biri olan ters lalenin özelliklerinden bahsedilmektedir. Etkinlikte iki farklı soru tipi kullanılmıştır. İlk olarak üç sorudan oluşan çoktan seçmeli soru tipi. İkinci olarak doğru yanlış soru 
tipi kullanılmıştır. Metin dil bilgisi yapısı genel olarak Avrupa Dil Portfolyosu'na göre B1 seviyesine uygundur. Ancak fiilimsilerin kullanıldığı gözlemlenmiştir. Fiilimsiler Avrupa Dil Portfolyosu’na göre B2'de yer almaktadır. Etkinlikteki kelime yapısı ise seviyeye uygundur. Dinleme metninin hızı ve anlaşılırlık derecesi Avrupa Dil Portfolyosu'na göre B1seviyesi için uygun düşünülebilir. Metinde görsel kullanılmamaktadır. Ancak ters laleyi ve özelliklerini anlatan bu dinleme metninde, bir ters lale görseli kullanılabilir. Görsel kullanımı öğrenmeyi daha kalıcı, dinlediğini anlamlandırmada ise yardımcıdır. Bu bağlamda öğrencinin belki de hayatında hiç görmediği ters lale kelimesini ilk kez duyduğunda belki çağrışım yapmayabilir. Bir ters lale görseli ile bu sorun ortadan kaldırılabilir. Ters lale ülkemizde yetişen nadide bir çiçek türü olduğu için dinleme etkinliğinde kullanımı yerinde ve uygundur. Kültür aktarımını sağlama bakımından da doğru olacağı düşünülmektedir.

\section{Dinleme 20}

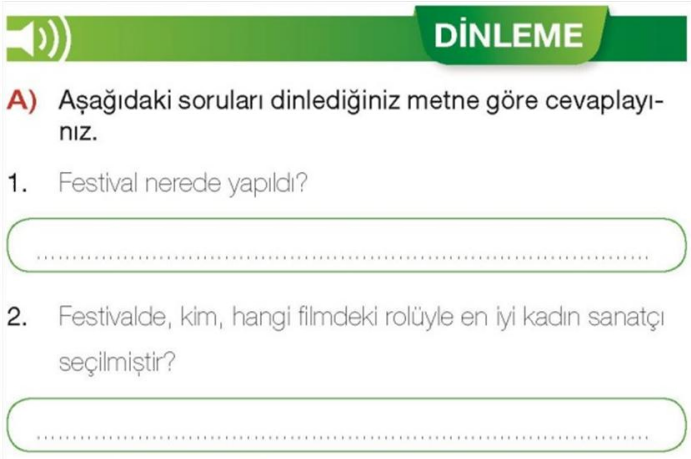

4. En iyi erkek oyuncunun filmde canlandırdı̈̆ı karakterin adl neydi?

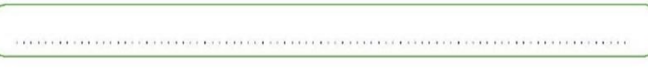

5. Festivalin en ly filmi hangisiydi?

3. Dereceye giren isimler ödüllerini kimlerden aldlar?

Şekil 2o. Gazi Üniversitesi yabancılar için Türkçe ders kitabı dinleme 20 görseli, 5. Ünite, Sayfa 92: “Altın Portakal"

Metnin içeriğinde Altın Portakal Film Festivali’nin Antalya'da yapıldı̆̆ 1 ve bu festivalde ödül alan sanatçllara değinilmiştir. Dinleme etkinliğinde altı açı uçlu soru bulunmaktadır. Metin dil bilgisi yapısı genel olarak Avrupa Dil Portfolyosu'na göre B1 seviyesine uygundur. Ancak az da olsa fiilimsilerin kullanıldığı gözlemlenmiştir. Fiilimsiler konusu Avrupa Dil Portfolyosu'na göre B2'de yer almaktadır. Etkinlikte kullanılan kelimeler ise seviyeye uygundur. Avrupa Dil Portfolyosu'na göre metnin hız ve anlaşlırlığı B1 seviyesi için uygun değildir. Dinleme etkinliği bir görsel ile desteklenmemiştir. Metnin içeriğinde Türkan Şoray, Kadir İnanır, Şener Şen gibi büyük usta oyunculara yer verilmiştir. Bu usta isimlerin yer alacağı bir görsel kullanımı yoktur. Unutulmamalıdır ki öğrencilerde ilgi uyandırmak adına görsel kullanımı önemlidir. Tüfekçioğlu’na (2014) göre dinleme öncesi etkinliklerde görsellerin kullanılması, ilgili metnin anlaşılırlığına olumlu etki eden bir uygulamadır.

\section{Sonuç, tartıșma ve öneriler}

Türkçe, günümüzde pek çok bölgede kalabalık bir nüfus tarafından konuşulan bir dildir. Yaygın olarak kullanılan bir dilin, yabancılar tarafından öğrenilmesi doğal bir hadisedir. Türkçeyi öğrenmek isteyen yabancıların bunu öğrenmekteki amaçları çeşitlilik gösterir. Akademik çalışmalar, ticari faaliyetler, diplomatik temaslar, Türklere olan sevgi, Avrupa Birliği’ne üyelik aşamasındaki bir Türkiye'yi tanıma vb. amaçlarla Türkçe öğrenilmek istenmektedir (Erdem, 2009: 889). Bu bağlamda Türkçenin yabancı 
Examination of Gazi University B1 level textbook listening department in teaching Turkish as a foreign language / M. Gün; M. Bakırdöğen (pp. 59-79)

dil olarak öğretimi oldukça önemlidir ve Türkçenin yabancı dil olarak öğretimine yönelik hazırlanmış çok sayıda ders kitabı vardır. Bu alanda yapılmış çok sayıda farklı çalışmalara rastlanmaktadır. Yabancı dil olarak Türkçe öğretimi alanında bugüne kadar birçok araştırma yapılmış, çok sayıda makale yazılmıştır, Çünkü Türkçenin yabancı dil olarak öğretimi yeni ve özel bir programdır öyle ki yabancı dil olarak Türkçenin öğretimi ülke sınırlarını aşarak yurtdışındaki pek çok ülkede etkin bir biçimde devam etmektedir. Bu programda toplam dört dil becerisi vardır. Bu beceriler okuma, yazma, dinleme ve konuşmadır. Her bir beceri çok önemlidir. Ancak dinleme becerisi dil öğrenmede son derece önemlidir. Yeni bir dil öğrenmede dinleme; konuşma, okuma ve yazma becerilerinin gelişimine temel oluşturur (Oxford,1993: 205-211). Dil becerilerinden okuma ve yazma, çocuklara genellikle örgün eğitimin başlamasıyla birlikte öğretilmeye başlarken dinleme "doğum öncesi anne karnında başlamakta, doğumdan sonra giderek gelişmekte ve diğer öğrenme alanlarına temel oluşturmaktadır" (Güneş, 2014: 80). Yabancılara Türkçe öğretiminde de tıpkı ana dili öğretiminde olduğu gibi anlama becerileri kapsamında dinleme ve okumaya öncelik verilmesi yararlı sonuçlar doğurabilir.

Günlük yaşamda çok sık kullanılan dinleme becerisi, öğrenci okuma ve yazma öğrenmeden önce önemli bir rol oynar, bu becerinin diğer becerilerle kuvvetli bir bağı vardır. Zira zihnimizden çlkmaması gerekir ki dil bir bütündür ve becerileri tam bir bütünlükle oluşur, unsurları birbiri arasında organik bir bağla bağlıdır (Recep, 1998: 85).

Dinleme becerisini olumlu ya da olumsuz etkileyen çok sayıda faktör vardır.

Özbay (2014: 157-174) dinlemeyi etkileyen faktörleri şöyle sıralar:

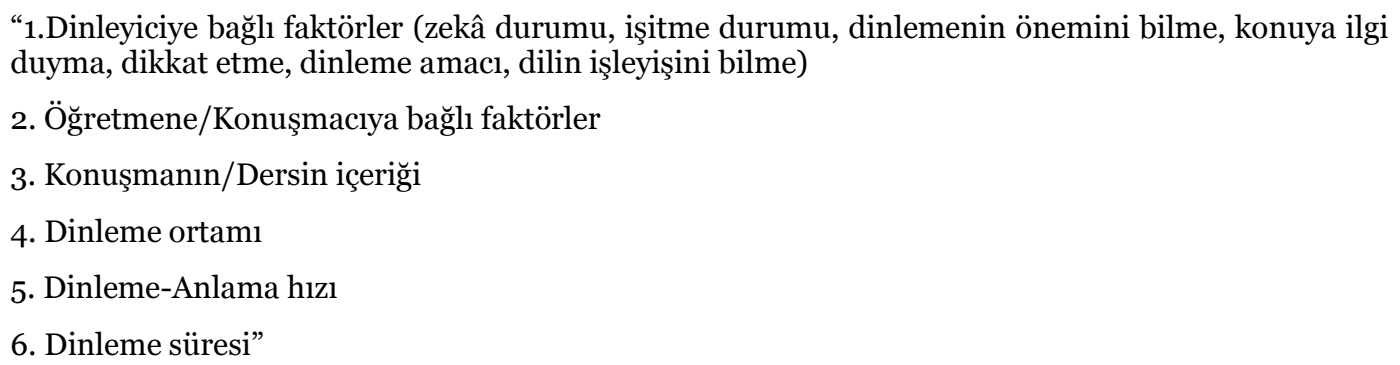

Alan yazın incelendiğinde araştırma konusuyla örtüşen Tabak ve Göçer (2017), Özbal ve Genç (2019), Şimşek (2016) gibi çalışmalar yapıldığı görülmektedir. Bu çalışmada ise Gazi Üniversitesi tarafından Türkçenin yabancı dil olarak öğretiminde kullanılan 2014 yılı basımı, B1 düzeyi ders kitabı ağırlıklı olarak dersin içeriği (ders kitabı) bağlamında incelenmiştir.

İnceleme konusunda esas alınan alt amaçlar şunlardır: Dinleme metninin içeriğĭ dinleme metninin soru tipi, dinleme metninin dil bilgisel yapısı ve B1 seviyesine uygunluğu, dinleme metninde yer alan kelimelerin seviyeye uygunluğu, dinleme etkinliğinde görsel kullanımı ve dinleme metninin varsa kültür aktarımı boyutu.

İncelenen B1 seviyesi ders kitabında toplam 5 ünite bulunmaktadır. Her bir ünitedeki dinleme etkinliği sayısı dörttür. Kitapta 20 adet dinleme etkinliği mevcuttur.

Bir dinleme materyalinde dinleme metninin içeriğinin açık, anlaşılır ve net olmasının öğrencinin kaygı düzeyini azaltacağı düşünülmektedir. 
Dinleme materyallerinin öğrencilerin ön bilgilerine yönelik olması gerektiği düşünülmektedir. Mesela, ders kitabındaki okuma metinleriyle dinleme metinlerinin birbirleriyle ilişkili olması dinleme becerisinde anlama ve anlamlandırmayı artırabilir. Okuma metnine yönelik dinleme aktivitesi tercih edilmelidir. Çünkü okuma ve dinleme birbirine benzeyen anlama süreçleridir.

Gazi Üniversitesi ders kitabındaki okuma metinleri ve dinleme metinleri arasında içerik bağlamında bir ilişki yoktur. Bu durumunun dinleme becerisinde anlama ve anlamlandırmayı desteklemediği düşünülmektedir.

Anlamanın önemli basamaklarından olan okuma; dinleme gibi bilgi alma yollarından biridir. Okuma, sonradan kazanılan ve zamanla gelişen bir davranış bütünüdür. Eğitim kurumlarında geliştirilen bir beceri alanıdır. Okuma becerisinin gelişimi okuma eğitimi ile mümkündür. Okuma "Bir metni gözle izleyip anlamını kavramak, gerekirse seslendirmek" tir (Sezer, 1991: 77; Akt. Sever, 2011: 12). Okuduğunu ve dinlediğini anlama becerileri birbirine çok benzeyen öğelerdir. Bu bağlamda okuma metinleriyle dinleme metinlerinin birbirini destekler nitelikte olması önemlidir.

Gazi Üniversitesi ders kitabındaki dinleme etkinliklerinde açık uçlu, çoktan seçmeli, doğru ve yanlışı işaretleme şeklinde farklı soru tipleri kullanılmıştır. Etkinliklerde farklı soru tipi kullanımının eleştirel ve çok boyutlu düşünmeyi etkin kılacă̆ düşünülmektedir.

Yılmaz (2007), Türkçe öğretiminde dinleme becerisini geliştirmeye yönelik önerilen etkinliklerin değerlendirilmesi üzerine bir çalışma yapmıştır. Deney grubuna hazırlanan etkinlikler uygulanmış, kontrol grubuna ise dinleme çalışması geleneksel biçimde yapılmıştır. Yapılan çalışmayla dinleme becerisinin düzeye uygun etkinliklerle geliştirilebileceği ortaya konulmuştur. Gazi Üniversitesi ders kitabındaki dinleme etkinliklerinde dinleme öncesi etkinliklere yer verilmemiştir. Dinleme öncesi etkinliklere yer verilmesinin öğrencide farklı dinleme özellliklerinin gelişmesine katkı sağlayacağı düşünülmektedir.

Temur (2010), dinleme metinlerinden önce ve sonra sorulan soruların üniversite öğrencilerinin dinlediğini anlama beceri düzeyine etkisinin olup olmadığını belirlemeyi amaçlayan yarı deneysel bir çalışma yapmıştır. Öğrencilerin uygulama sürecine yönelik görüşleri alınmış ve içerik çözümlemesi yapılmıştır. Araştırmadan elde edilen bulgulara göre metin öncesinde verilen soruların dinlediğini anlama beceri düzeyine olan etkisi, metni dinledikten sonra verilen sorulara göre daha büyüktür. Dinleme metni öncesinde soruların bilinmesi konunun ve amacın belirlenmesine katkı yapmaktadır. Metin öncesinde sorulan sorular öğrencilerin seçici birer dinleyici olmalarına zemin oluşturmaktadır. Sorular metinden sonra sorulduğunda ise öğrenciler metni bir bütün olarak dinleme eğiliminde ve daha etkin dinledikleri fikrindedirler.

Gazi Üniversitesi ders kitabındaki dinleme etkinliklerinde kullanılan dil bilgisel yapısı genel olarak Avrupa Dil Portfolyosuna uyumludur. Bazı metinlerde üst seviyeleri uygun dilbilgisel yapısı kullanıldığı gözlemlenmiştir.

Yabancllara Türkçe öğretimi, günümüzdeki popülerliğine karşın birçok sorunu da beraberinde getirmiştir. Bunların başında Türkçenin gramerindeki tasnif, tanımlama ve işlev sorunu gelmektedir.Özellikle kimi gramer konularının yabancılara anlatımında güçlük çekilmektedir. Bu sorunların ortaya çıkmasındaki temel gerekçelerden birisi, Türk dil bilgisinin yeterince iyi 
Examination of Gazi University B1 level textbook listening department in teaching Turkish as a foreign language / M. Gün; M. Bakırdöğen (pp. 59-79)

işlenememesidir(Gümüş, 2016). Bu nedenle diğer beceriler yanında yabancllara Türkçe öğretimine yönelik dinleme etkinliklerinde de seviyeye uygun dil bilgisi yapılarına yer verilmesi faydalı olabilir.

Gazi Üniversitesi ders kitabındaki dinleme etkinliklerinde kullanılan kelimeler genellikle Avrupa Dil Portfolyosuna uyumludur. Kelime edinimi dil öğretiminde oldukça önemli bir yere sahiptir. Nitekim Yabancı dil olarak Türkçe öğretiminde, kelime öğretimini destekler birçok çalışma bulunmaktadır.

Yabancı dil olarak Türkçe öğretiminde öğrencilerin kelime öğrenmesi öğrenme sürecinin her aşamasında gerçekleşen bir olgudur. Öğrencilere yabancı dil öğretilirken onların sürekli yeni kelimeler öğrenmesi ve kullanması teşvik edilir. "En basit bir istekten karmaşık yapıdaki duygu ve düşünceler kelimeler yardımıyla anlatılır. Bu yüzden kelime öğretimi, dil öğretiminin temeli sayılır” (Doğan, 2014, s. 89). Yabancı bir dilde kelime öğrenme hemen gerçekleşen bir eylem olmaktan ziyade bilinçli bir çalışma ve sürekli tekrar sonucu ortaya çıkar. Bu çalışmalar ve tekrarlar sınıf içinde yeterli zaman olmadığından sınıf dışında da devam eder. Bu durum öğrencinin kendi başına kelime öğrenmeye çalışması demektir. Öğrencilerin çoğu yabancı bir dil öğrenmeye başladıklarında kendi başına kelime öğrenmeye çalışır. Bu süreçte öğrenciler tamamen kendi ilgi ve ihtiyaçları doğrultusunda kelime öğrenir (Apaydın, 2007). Öğrenciler kendine uygun bir kelime öğrenme stratejisi ile yeni kelimeler öğrenmeye çalışırlar.

Gazi Üniversitesi ders kitabındaki dinleme etkinliklerinde toplam 20 adet dinleme etkinliğinin 13 tanesinde hiç görsel kullanılmamıştır. 3 tanesinde ise kullanılan görsel, dinleme metinlerini destekler nitelikte olamayıp, oldukça yetersizdir. Metin görsel uyumunun metnin anlaşılırlığını artıracağı düşünülmektedir. Tüfekçioğlu (2014) da çalışmasında, dinlemede görsellerin kullanılmasının metnin anlaşılırlığına etki eden bir uygulama olduğunu söylemiştir. Bu nedenle dinleme metinlerinde görsel kullanımı oldukça büyük bir öneme sahiptir. Kullanılan görsellerin dinleme metninin anlamını destekler nitelikte olması gerektiği söylenebilir.

Yabancılara Türkçe öğretmek için hazırlanmış ders kitaplarının Türkçe öğrenen yabancılara Türk kültürünü de öğretmesi planlanmalıdır. Türk kültürünü öğretmek adına asıl hedef olan dil öğretimi ikinci plana atılmamalı, kültürel ögeler ders kitabına anlamlı ve dozunda yerleştirilmelidir. Çünkü Türk kültüründen uzak bir yabancllara Türkçe kitabı düşünülemez (Duman, 2003: 152). İncelenen Gazi Üniversitesi B1 ders kitabındaki dinleme etkinliklerinde Türk kültürüne ait unsurlara yeterince yer verilmediği ifade edilebilir.

\section{Çalışma verilerinden hareketle geliştirilen öneriler şu şekilde sıralanabilir:}

-Yabancı dil olarak Türkçe kitaplarında dinleme metinleriyle ilgili etkinliklere daha fazla yer verilebilir.

- Gazi Üniversitesi B1 seviye ders kitabındaki dinleme metinlerinde Türk kültürünü yansitan metinlerin az olduğu gözlendiğinden, Türk kültürünü içeren metinlerin sayı ve niteliği geliştirilmeye çalışılmalıdır.

- Gazi Üniversitesi B1 seviye ders kitabındaki okuma metinleri ve dinleme metinleri arasında içerik bağlamında daha fazla ilişki kurularak öğrencilerin metni anlama olanakları artırılmalıdır.

- Gazi Üniversitesi B1 seviye ders kitabındaki dinleme etkinliklerindeki görsellerin sayısı ve dinleme metniyle örtüşme düzeyi geliştirilmelidir. 
- Öğrencilerin dinleme metinlerini daha kolay anlayabilmeleri için Gazi Üniversitesi B1 seviye ders kitabında dinleme öncesi etkinliklere de yer verilmelidir.

\section{Kaynakça}

Aktaş, Ş. ve Gündüz, O.(2007). Yazılı ve sözlü anlatım. Ankara: Akçă̆ yayınları.

Apaydın, D. (2007). Türkçenin yabancı dil olarak öğretiminde sözcük öğretimi üzerine bir yöntem denemesi. Yayımlanmamış Yüksek Lisans Tezi, Ankara: Ankara Üniversitesi Sosyal Bilimler Enstitüsü.

CEFR. (2001). A Common European Framework of Reference for Languages: Learning, Teaching, Assesment. Strasbourg: Modern Language Division.

Doğan, Y. (2014). Yabancılara Türkçe kelime öğretiminde market broşürlerinden yararlanma. Journal of Language and Linguistic Studies, 10(1), 89-98.

Dara,R. (2000). Yazılı anlatıma Giriş . İstanbul: Asa Kitabevi

Duman, A. (2003). Türk soylulara Türkiye Türkçesi öğretiminde metin seçimi. TÜBAR. XIII, 151-154. Erdem, İlhan (2009). "Yabancılara Türkçe Öğretimiyle İlgili Bir Kaynakça Denemesi", Turkish Studies, 4-3,888-937.

Göçer, A. \& Moğul, S. (2011). Türkçenin yabancı dil olarak öğretimi ile ilgili çalışmalara genel bir bakış. Turkish Studies - International Periodical For The Languages, Literature and History of Turkish or Turkic. 6(3). 797- 810 .

Gümüş, İ.(2016).Türkçede Emir-İstek Kipi ve Yabancllara Türkçe Öğretimi, SUTAD, Bahar 2016; (39): 253-262e-ISSN 2458-9071

Güneş, F. (2014). Türkçe öğretimi yaklaşımlar ve modeller. Ankara: Pegem AkademiYayınları.

Özbal, B. ve Genç, A. (2019). Yabancı Dil Olarak Türkçe Öğretimi Ders Kitaplarında Dinleme Becerisi Alanında Kullanılan Alıştırmaların Değerlendirilmesi. SEFAD, 42, 197-212.

Özbay, M. (2014). Anlama teknikleri: I. Dinleme eğitimi. Ankara: Öncü Kitap.

R. L Oxford, “Research Update on Teaching L2 Listening”, System, 21 (2), 1993, 205-211.

Rost, M. (2001). Listening [Dinleme]. In R. Carter and D. Nunan (Eds.), The Cambridge guide to teaching English to speakers of other languages [Diğer dillerin kullanıcılarına İngilizce öğretmek için Cambridge rehberi] (pp. 7-13). Cambridge: Cambridge University Press. https://doi.org/10.1017/CBO9780511667206.002 Erişim Tarihi: 02.06.2020

Sever, S. (2011). Türkçe Öğretimi ve Tam Öğrenme. 5. Baskı. Ankara: Anı Yayıncılık.

Şimşek, R. (2016). Yabancılara Türkçe Öğretiminde Kullanılan Ders Kitaplarının Temel Dil Becerileri Bağlamında Karşılaştırmalı Olarak İncelenmesi. Basılmamış Yüksek Lisans Tezi, Nevşehir Hacı Bektaş Veli Üniversitesi, Nevşehir.

Tabak, G. ve Göçer, A. (2017). Türkçenin Yabancı Dil Olarak Öğretiminde A1-C1 Düzey Dinleme Etkinliklerinin İncelenmesi. Cumhuriyet Uluslararası Eğitim Dergisi, 6(3), 400-411.

Temur, T. (2010). Dinleme Metinlerinden Önce ve Sonra Sorulan Soruların Üniversite Öğrencilerinin Dinlediğini Anlama Beceri Düzeyine Etkisi. Selçuk Üniversitesi Ahmet Keleşoğlu Eğitim Fakültesi Dergisi, 303-319.

Tüfekçioğlu, B. (2014). Yabancı dil olarak Türkçe öğretiminde dinleme etkinlikleri ile sözcük öğretimi üzerine bir araştırma: Çukurova TÖMER örneği. E-Dil Dergisi, 2, 35-51.

Yıldırım, A. ve Şimşek, H. (2013). Sosyal bilimlerde nitel araştırma yöntemleri (Genişletilmiş 9. baskı). Ankara: Seçkin Yayıncılık.

Yılmaz, İ. (2007). Türkçe Öğretiminde Dinleme Becerisini Geliștirmeye Yönelik Önerilen Etkinliklerin Değerlendirilmesi, (Yayınlanmamış Yüksek Lisans Tezi). Niğde: Niğde Üniversitesi Sosyal Bilimler Enstitüsü. 